\title{
Effect of Changing the Effluent Path of Omar-Bek Drain on the Damietta Branch Water Quality
}

\author{
Mohamed K. Mostafa*, Robert W. Peters \\ Department of Civil, Construction, and Environmental Engineering, University of Alabama at Birmingham, \\ Birmingham, USA \\ Email: "mkhaled@uab.edu
}

Received 6 June 2015; accepted 10 January 2016; published 13 January 2016

Copyright (C) 2016 by authors and Scientific Research Publishing Inc.

This work is licensed under the Creative Commons Attribution International License (CC BY). http://creativecommons.org/licenses/by/4.0/

(c) (i) Open Access

\section{Abstract}

The Omar-Bek drain, which represents the main source of water pollution along the Damietta branch of the Nile River, receives about $600,000 \mathrm{~m}^{3}(158,503,200$ gallons) daily of untreated domestic, agricultural, and industrial wastes. The main purpose of this research consisted of investigating alternatives of managing water quality at the Damietta branch; a comparison was conducted between the current situation and two proposed scenarios. The first scenario involved changing the effluent path of the Omar-Bek drain to another drain is called "Main Western drain". The second scenario centered around improving water quality at the Omar-Bek drain by constructing a WWTP with a design capacity of more than $150,000 \mathrm{~m}^{3} /$ day $(39,625,800$ gallons $)$ and by improving water quality at this drain by increasing the efficiency of WWTPs that discharged daily about $60,000 \mathrm{~m}^{3}(15,850,300$ gallons $)$ of partially treated wastewater to the drain. The current situation and the two proposed scenarios were simulated by using river pollutant (RP) modeling. It was concluded that the Omar-Bek drain has no significant effect on the Damietta branch water quality and that, instead of changing the path of the drain, improving the efficiency of the existing WWTPs discharging to the Omar-Bek drain and preventing the direct discharge of domestic wastewater to the drain will provide the most effective ways of increasing the water quality of the Damietta branch.

\section{Keywords}

Omar-Bek Drain, River Pollutant Modeling, Damietta Branch, Nile River, Egypt

\footnotetext{
${ }^{*}$ Corresponding author.
}

How to cite this paper: Mostafa, M.K. and Peters, R.W. (2016) Effect of Changing the Effluent Path of Omar-Bek Drain on the Damietta Branch Water Quality. Journal of Water Resource and Protection, 8, 20-30. 


\section{Introduction}

The rapid population growth in Egypt significantly expanded the volume of industrial and agricultural activities [1]. Consequently, this expansion resulted in increased water demand and reduced per capita water availability. The population of Egypt in 2014 was 83.4 million and is projected to increase to 115 million by 2050, leading to increased water demand [2]. This greater demand indicates the importance of protecting available water resources from potential pollution. Egypt suffers from poor water quality caused by the lack of planning and by the discharge of industrial and agricultural waste and from sewage and solid waste that flows from cities and villages to the Nile River without prior treatment [3] [4]. The Nile River downstream of Delta Barrages divides into two branches, the Damietta and the Rosetta. The Damietta branch extends about $242 \mathrm{~km}$ (150.37 miles) from downstream of Delta Barrages to the Mediterranean Sea [5] and has an average velocity of about $0.35 \mathrm{~m} / \mathrm{s}$ and an average depth of about $3.25 \mathrm{~m}$ [6] [7]. The top width of the Damietta branch ranges from 200 to $250 \mathrm{~m}$, and the sinuosity ranges from 2.4 to 2.9 [7] [8]. At a distance of $129 \mathrm{~km}$ downstream of Delta Barrages, the Damietta branch receives discharge from the Omar-Bek drain. This drain, located in El-Gharbia governorate, starts from Zefta City and ends at Samanoud City and receives pollution loads from domestic, agricultural, and industrial wastes discharged from villages, cites, and drains located along its path [5] [7].

Several studies have been conducted to address water quality at the Damietta branch. In a 2010 study, Abdo collected water samples from seven stations along the branch, starting from El-Kanater El-Khyria Barrage and ending at Damietta estuary, and concluded that the change in water quality at the Damietta branch resulted from thermal pollution, climatic conditions, agricultural wastes stored behind Faraskour Dam, and sewage wastes at El-Serw City [9]. In a 2012 study, Ezzat and Reham investigated the effect of the Omar-Bek drain on the Damietta branch water quality [5]. Water samples were collected at the discharge point of the Omar-Bek drain and downstream and upstream of the discharge point. The water quality index was calculated, and the results led to classifying the surface water quality upstream of the Omar-Bek drain as good and the surface water downstream of the drain as marginal. It was also determined that the concentrations of heavy metals (aluminum, iron, selenium, arsenic, zinc, copper, manganese, barium, chromium, cadmium, tin, lead, nickel, cobalt, and vanadium) at the Omar-Bek drain and upstream and downstream of the drain did not exceed the permissible limits specified in Egyptian law 48/1982 [10].

After the revolution of 25 January 2011, some members of the Egyptian parliament conducted hearings on water quality. The irrigation ministry in Egypt plans to change the path of the Omar-Bek drain to the Main Western drain. The total cost of changing the effluent path of the Omar-Bek drain approximates \$25 million, which includes the cost of constructing a drain of $22 \mathrm{~km}$ [7]. The main goal of this research involved evaluating the validity of this decision and its impact on the Damietta branch water quality.

\section{Materials and Methods}

The study area encompassed about $119 \mathrm{~km}$ (73.94 miles) of the Damietta branch and extended from upstream of the Omar-Bek drain to Faraskour City. Figure 1 depicts a map of the study areas.

The concentrations of different parameters were simulated along the study area at the Damietta branch for the current situation and the two proposed scenarios (changing the effluent path of the Omar-Bek drain and improving water quality at the drain) using river pollutant (RP) modeling. The RP modeling is a river water quality model uses mass balance and exponential equations to calculate different parameters at different points along the study area [7]. The parameters included is solved oxygen (DO), biological oxygen demand (BOD), chemical oxygen demand (COD), chlorides $\left(\mathrm{Cl}^{-}\right)$, total organic carbon (TOC), total suspended solids (TSS), total dissolved solids (TDS), $\mathrm{pH}$, and temperature [7]. Equation (1) was used to calculate the flow downstream each pollution source. Equation (2) was used calculate the value of $\mathrm{pH}$ downstream of each point source, while Equation (3) was used to calculate the values of TDS, $\mathrm{Cl}^{-}$, TOC, DO, BOD, TDS, and TSS downstream of the point source.

$$
\begin{gathered}
Q_{\text {river, upstream }}+Q_{\text {source }}=Q_{\text {river,downstream }} \\
\mathrm{pH}_{\text {river,downstream }}=-\log \left[\frac{Q_{\text {river, upstream }} \times\left(10^{- \text {pHriver, upstream }}\right)+Q_{\text {source }} \times\left(10^{- \text {pHsource }}\right)}{Q_{\text {river, downstream }}}\right]
\end{gathered}
$$






Figure 1. Study area at the Damietta branch.

$$
Q_{\text {Source }} \times C_{\text {Source }}+Q_{\text {river, upstream }} \times C_{\text {river,upstream }}=Q_{\text {river,downstream }} \times C_{\text {river, downstream }}
$$

Assumptions associated with the calculations procedure included a steady-state concentration and a complete mixing along the Damietta branch, as well as first order decay equal to 0.1 day $^{-1}$ at $20^{\circ} \mathrm{C}$ [7]. Equation (4) was used to estimate the decay rate at any water temperature [11].

$$
K_{T}=K_{20^{\circ} \mathrm{C}} \times 1.047^{(T-20)}
$$

where $K_{20^{\circ} \mathrm{C}}=$ decay at $20^{\circ} \mathrm{C}$ and $T=$ temperature.

The exponential equation was used to calculate the concentration of different parameters at any point located downstream each point source [12], see Equation (5).

$$
C=C_{o} \times \mathrm{e}^{(-k x / v)}
$$

where $C=$ pollutant concentration at any point located after the point source, $\mathrm{mg} / \mathrm{L}$;

$C_{o}=$ pollutant concentration immediately downstream of the injection point, $\mathrm{mg} / \mathrm{L}$;

$x=$ distance downstream of the injection point, $\mathrm{m}$;

$v=$ velocity in the river, $\mathrm{m} /$ day;

$k=$ first-order decay constant, day ${ }^{-1}$.

Before the RP modeling was run, water samples were collected upstream of the Omar-Bek drain and from three point sources located along the branch: the Omar-Bek drain, Talkha power station, and Kafr Al-Batek power station. Analysis of the water samples included determination of the levels of the TOC, TDS, TSS, BOD, $\mathrm{COD}, \mathrm{pH}, \mathrm{Cl}^{-}$, and DO. The samples were analyzed for different parameters according to the standard methods for wastewater analysis [13]. The HM digital TDS meter was used to measure the TDS concentration in the field. For quality control purposes, a solution with known concentration allowed assessment of the accuracy of measurements. The WTW multi 340i meter enabled measurement of pH and DO values in the field. Four buffer solutions with $\mathrm{pH}$ values of $4.0,7.0$, and 10.0 were used for the multi meter calibration. The meter automatically adjusts DO. Analysis of the other parameters took place in Egyptian Housing Building Research Center (HBRC) laboratory, located in Cairo city. This laboratory received an ISO 9000 award for quality assurance. The chlorides $\left(\mathrm{Cl}^{-}\right)$concentration was measured by applying ion chromatography method 4110B. For quality control purposes, the sample loop and the needle were flushed with $250.0 \mathrm{~mL}$ of deionized water; the temperature of the column was set at $30^{\circ} \mathrm{C}$. After running occurred, the time and the resolution of the peaks were checked. The time and the resolution of the peaks must approximate those of the chromatogram of the column. The 5-day BOD Test 5210B was used in the determination of the BOD concentration in wastewater samples. For quality control purposes, the research protocol included the following procedures: 1 ) In seed control samples tested after 5 days 
of incubation, a minimum residual DO of $1.0 \mathrm{mg} / \mathrm{L}$ and a minimum DO depletion of $2.0 \mathrm{mg} / \mathrm{L}$ were required; 2) the glucose-glutamic acid solution and the dilution water were tested and compared with the acceptable limits. Use of the closed reflux, titrimetric method 5220C enabled determination of the COD concentration in the samples. For quality control purposes, testing of a solution with known concentration ensured accuracy of the measurements. The TOC concentration was measured in the laboratory by using a Shimadzu TOC-4200 analyzer; an automatic calibration conducted by using dilution water as a standard solution ascertained the accuracy of the data. Test method 2540D was used for the determination of TSS. For quality control purposes, analysis of $20 \%$ of the total number of sample took place.

The other parameters needed to run the RP modeling included the flow rate and velocity upstream of the Omar-Bek drain, the flow velocity downstream of each point source, the flow rate at each point source located along the study area, and the distance between the point sources.

The variables in the three models were the data at the Omar-Bek drain. In the case of changing the effluent path, the Omar-Bek drain will not discharge water to the Damietta branch; therefore, the data from the OmarBek drain were excluded during the running of the modeling. Mass balance equations were used to estimate the concentrations of different parameters at the Omar-Bek drain after application of the second scenario (improving water quality at the Omar-Bek drain). The data for each scenario were separately entered to the RP modeling, and the modeling was run. Then, a graph for each parameter was created to simulate the pollutant transport along the study area. The next step involved comparing the analytical results of each modeling with water quality standards specified in Egyptian law 48/1982 and EPA standards [10] [14]. Finally, a comparison was conducted between the current situation and the two proposed scenarios to determine the most suitable scenario.

\section{Results and Discussion}

In case of the second scenario (improving water quality at the Omar-Bek drain), the concentration of different parameters at the Omar-Bek drain were estimated using the mass balance approach, as shown in following equations (summarized in Table 1):

$$
\left(Q_{\text {Sewage }} \times C_{\text {Sewage }}\right)+\left(Q_{\text {Agriculture }} \times C_{\text {Agricultural }}\right)+\left(Q_{\text {wWTPs }} \times C_{\text {WWTPs }}\right)=Q_{\text {expected }} \times C_{\text {expected }} .
$$

For COD:

$$
\begin{aligned}
& \left(1.5 \times 10^{5} \mathrm{~m}^{3} \times 70 \mathrm{mg} / \mathrm{L}\right)+\left(3.9 \times 10^{5} \mathrm{~m}^{3} \times 31 \mathrm{mg} / \mathrm{L}\right)+\left(6 \times 10^{4} \mathrm{~m}^{3} \times 70 \mathrm{mg} / \mathrm{L}\right)=6 \times 10^{5} \mathrm{~m}^{3} \times C_{\text {expected }} \\
& \therefore C_{\text {expected }}=44.65 \mathrm{mg} / \mathrm{L} .
\end{aligned}
$$

For BOD:

$$
\begin{aligned}
& \left(1.5 \times 10^{5} \mathrm{~m}^{3} \times 34.5 \mathrm{mg} / \mathrm{L}\right)+\left(3.9 \times 10^{5} \mathrm{~m}^{3} \times 17.13 \mathrm{mg} / \mathrm{L}\right)+\left(6 \times 10^{4} \mathrm{~m}^{3} \times 34.5 \mathrm{mg} / \mathrm{L}\right)=6 \times 10^{5} \mathrm{~m}^{3} \times C_{\text {expected }} \\
& \therefore C_{\text {expected }}=23.20 \mathrm{mg} / \mathrm{L} .
\end{aligned}
$$

For TSS:

$$
\begin{aligned}
& \left(1.5 \times 10^{5} \mathrm{~m}^{3} \times 30 \mathrm{mg} / \mathrm{L}\right)+\left(3.9 \times 10^{5} \mathrm{~m}^{3} \times 30.5 \mathrm{mg} / \mathrm{L}\right)+\left(6 \times 10^{4} \mathrm{~m}^{3} \times 30 \mathrm{mg} / \mathrm{L}\right)=6 \times 10^{5} \mathrm{~m}^{3} \times C_{\text {expected }} \\
& \therefore C_{\text {expected }}=30.30 \mathrm{mg} / \mathrm{L} .
\end{aligned}
$$

For DO:

$$
\begin{aligned}
& \left(1.5 \times 10^{5} \mathrm{~m}^{3} \times 4 \mathrm{mg} / \mathrm{L}\right)+\left(3.9 \times 10^{5} \mathrm{~m}^{3} \times 4.5 \mathrm{mg} / \mathrm{L}\right)+\left(6 \times 10^{4} \mathrm{~m}^{3} \times 4 \mathrm{mg} / \mathrm{L}\right)=6 \times 10^{5} \mathrm{~m}^{3} \times C_{\text {expected }} \\
& \therefore C_{\text {expected }}=4.325 \mathrm{mg} / \mathrm{L} .
\end{aligned}
$$

For TDS:

$$
\begin{aligned}
& \left(1.5 \times 10^{5} \mathrm{~m}^{3} \times 400 \mathrm{mg} / \mathrm{L}\right)+\left(3.9 \times 10^{5} \mathrm{~m}^{3} \times 721 \mathrm{mg} / \mathrm{L}\right)+\left(6 \times 10^{4} \mathrm{~m}^{3} \times 400 \mathrm{mg} / \mathrm{L}\right)=6 \times 10^{5} \mathrm{~m}^{3} \times C_{\text {expected }} \\
& \therefore C_{\text {expected }}=608.65 \mathrm{mg} / \mathrm{L} .
\end{aligned}
$$


Table 1. Water flow and characterization at the Omar-Bekdrain.

\begin{tabular}{ccc}
\hline Term & Current situation & Second scenario \\
\hline Flow, $\mathrm{m}^{3} / \mathrm{day}$ & 600,000 & 600,000 \\
BOD, $\mathrm{mg} / \mathrm{L}$ & 55.0 & 23.20 \\
COD, $\mathrm{mg} / \mathrm{L}$ & 97.0 & 44.65 \\
TOC, $\mathrm{mg} / \mathrm{L}$ & 1.80 & 1.62 \\
TDS, $\mathrm{mg} / \mathrm{L}$ & 700 & 608.65 \\
TSS, $\mathrm{mg} / \mathrm{L}$ & 160 & 30.30 \\
DO, mg/L & 3.90 & 4.325 \\
$\mathrm{Cl}{ }^{-}, \mathrm{mg} / \mathrm{L}$ & 130 & 122.40 \\
$\mathrm{pH}, \mathrm{dimensionless}$ & 7.50 & 7.90 \\
\hline
\end{tabular}

Second scenario: improving water quality at the Omar-Bekdrain.

For TOC:

$\left(1.5 \times 10^{5} \mathrm{~m}^{3} \times 0.7 \mathrm{mg} / \mathrm{L}\right)+\left(3.9 \times 10^{5} \mathrm{~m}^{3} \times 2.13 \mathrm{mg} / \mathrm{L}\right)+\left(6 \times 10^{4} \mathrm{~m}^{3} \times 0.7 \mathrm{mg} / \mathrm{L}\right)=6 \times 10^{5} \mathrm{~m}^{3} \times C_{\text {expected }}$

$\therefore C_{\text {expected }}=1.62 \mathrm{mg} / \mathrm{L}$.

For $\mathrm{Cl}^{-}$:

$\left(1.5 \times 10^{5} \mathrm{~m}^{3} \times 70 \mathrm{mg} / \mathrm{L}\right)+\left(3.9 \times 10^{5} \mathrm{~m}^{3} \times 150.73 \mathrm{mg} / \mathrm{L}\right)+\left(6 \times 10^{4} \mathrm{~m}^{3} \times 70 \mathrm{mg} / \mathrm{L}\right)=6 \times 10^{5} \mathrm{~m}^{3} \times C_{\text {expected }}$

$\therefore C_{\text {expected }}=122.40 \mathrm{mg} / \mathrm{L}$.

For $\mathrm{pH}$ :

$Q_{\text {Sewage }} \times\left(10^{-\mathrm{pH}_{\text {Sewage }}}\right)+Q_{\text {Agricultural }} \times\left(10^{-\mathrm{pH}_{\text {Agricultural }}}\right)+Q_{\text {WWTPs }} \times\left(10^{-\mathrm{pH}_{\text {WWTPs }}}\right)=Q_{\text {expected }} \times\left(10^{-\mathrm{pH}_{\text {expected }}}\right)$

$1.5 \times 10^{5} \mathrm{~m}^{3} \times\left(10^{-7.72}\right)+3.9 \times 10^{5} \mathrm{~m}^{3} \times\left(10^{-8.1}\right)+6 \times 10^{4} \mathrm{~m}^{3} \times\left(10^{-7.72}\right)=6 \times 10^{5} \mathrm{~m}^{3} \times\left(10^{-\mathrm{pH}_{\text {expected }}}\right)$

$\therefore \mathrm{pH}_{\text {expected }}=7.90$.

For the first scenario (changing the effluent path of the Omar-Bek drain), the data from the Omar-Bek drain were excluded during the running of the modeling. Water flow and characterization at the Omar-Bek drain for the current situation and the second proposed scenario, are presented in Table 1. The RP modeling was then used to simulate pollutant transport for the three scenarios.

\subsection{Modeling Results}

The simulations of the current situation and the two scenarios are shown in Figures 2-9. Figure 2 shows the predicted BOD concentration for the current situation and the two proposed scenarios along the study area. The BOD concentration upstream of the Omar-Bek drain measured about $2.0 \mathrm{mg} / \mathrm{L}$, which agrees with water quality standards specified in Egyptian law 48/1982 and EPA standards (<6.0 mg/L) [10] [14]. After the Damietta branch received discharge from the Omar-Bek drain, the BOD concentration at the branch increased to 3.33 $\mathrm{mg} / \mathrm{L}$, a figure still within the limits specified by Egyptian and EPA standards. Consequently, discharge from the Omar-Bek drain did not significantly affect the BOD concentration. The highest BOD concentration was recorded directly downstream of the Talkha power station, where it reached 5.2, 4.13, and $4.6 \mathrm{mg} / \mathrm{L}$ for the current situation, the first scenario (changing the effluent path of the Omar-Bek drain), and the second scenario (improving water quality at the Omar-Bek drain), respectively; these levels also remained within the limits specified by Egyptian law and EPA standards. Applying the first scenario will reduce the BOD concentration from 3.33 to $2.0 \mathrm{mg} / \mathrm{L}$ downstream of the Omar-Bek drain; while applying the second scenario will reduce the BOD concentration from 3.33 to $2.50 \mathrm{mg} / \mathrm{L}$ (see Figure 2). Consequently, applying both scenarios has a minor impact on reducing the BOD concentration in the Damietta branch. 
Figure 3 shows the predicted DO concentration for the three scenarios along the study area. The DO concentration upstream of the Omar-Bek drain was approximately $6.10 \mathrm{mg} / \mathrm{L}$, which agrees with water quality standards specified in Egyptian law 48/1982 and EPA standards ( $\geq 4.0 \mathrm{mg} / \mathrm{L}$ ) [10] [14]. The DO concentration at the Damietta branch decreased to $6.0 \mathrm{mg} / \mathrm{L}$ after the branch received discharge from the Omar-Bek drain. Applying the proposed solutions will have a negligible effect on the concentration of the DO, where applying the first scenario is expected to increase the DO concentration downstream the Omar-Bek drain from 6.0 to $6.10 \mathrm{mg} / \mathrm{L}$, while applying the second is expected to increase the DO concentration from 6.0 to $6.05 \mathrm{mg} / \mathrm{L}$ (see Figure 3). Consequently, the Omar-Bek drain slightly reduced the DO concentration in the Damietta branch.

The water quality standard for TDS is $500 \mathrm{mg} / \mathrm{L}$ (Egyptian Law 48/1982 and EPA Standards) [10] [14]. The TDS concentration upstream of the Omar-Bek drain, $190 \mathrm{mg} / \mathrm{L}$, met the water quality standards (see Figure 4). After discharge was received from the Omar-Bek drain, the TDS concentration at the Damietta branch increased to $202.6 \mathrm{mg} / \mathrm{L}$, a figure still within the limit specified by Egyptian and EPA standards. In the current situation, the TDS concentration along the study area remained within the limits specified in Egyptian and EPA standards.

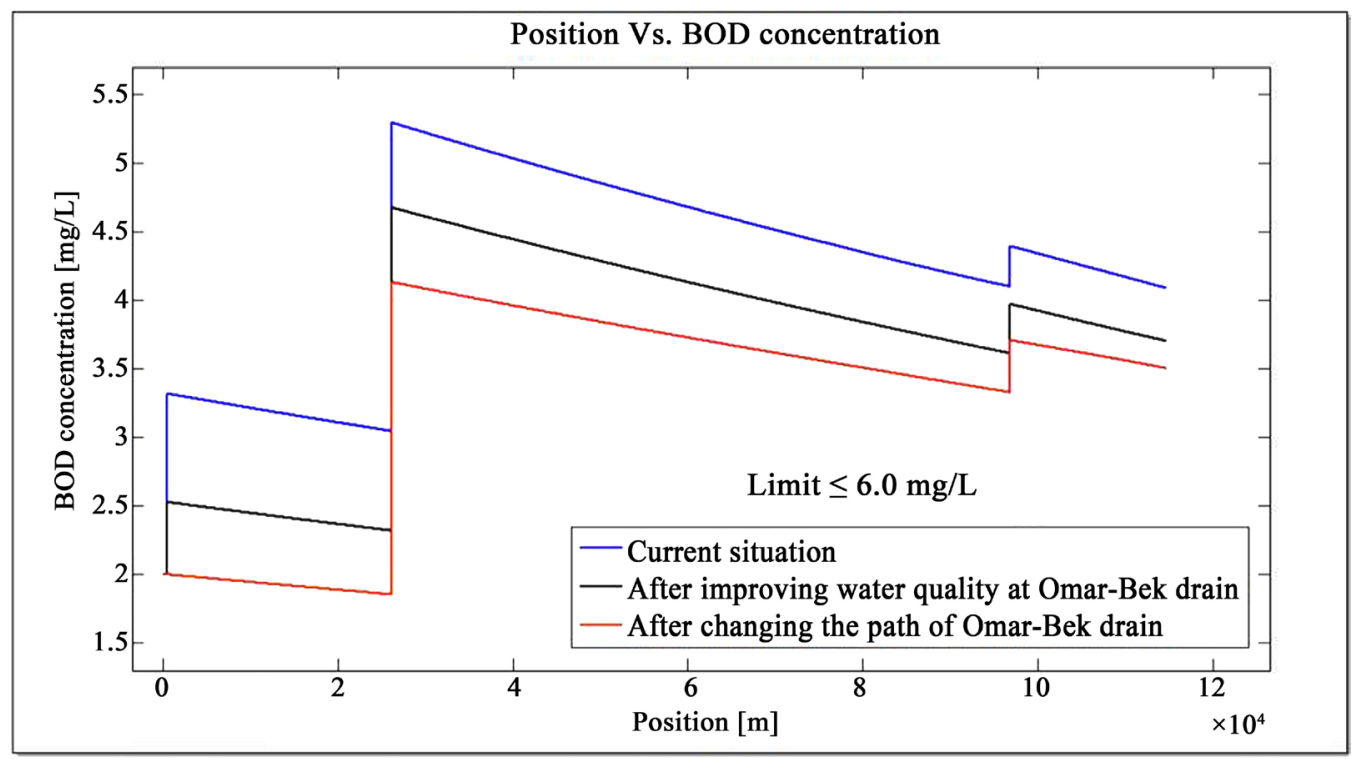

Figure 2. BOD concentration along the Damietta branch for current situation and proposed solutions.

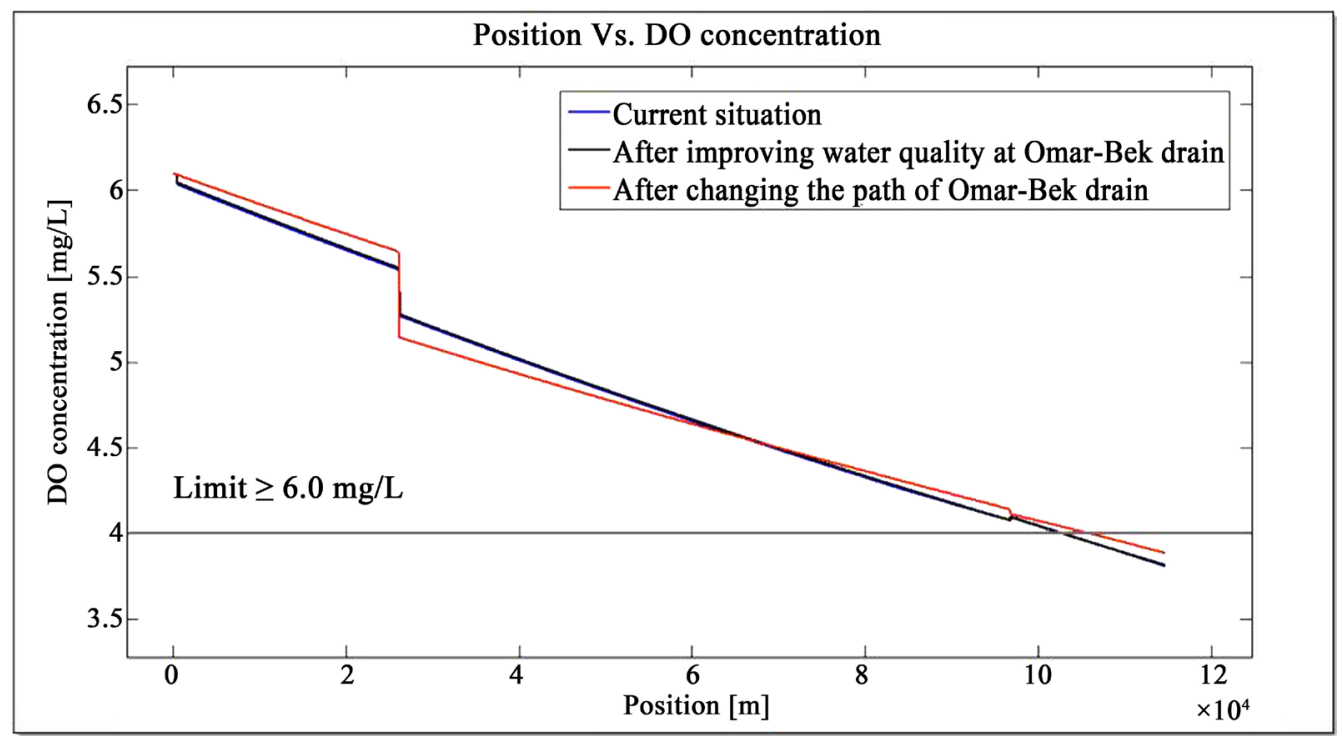

Figure 3. DO concentration along the Damietta branch for current situation and proposed solutions. 
Applying the first scenario is expected to decrease the TDS concentration downstream the Omar-Bek drain from 202.60 to $190.0 \mathrm{mg} / \mathrm{L}$, while applying the second is expected to decrease the DO concentration from 202.60 to $200.0 \mathrm{mg} / \mathrm{L}$ (see Figure 4). Consequently, the discharge from the Omar-Bek drain did not adversely affect TDS concentration in the Damietta branch and applying the proposed solutions will have a slight effect on the concentration of the TDS in the Damietta branch.

Figure 5 shows the predicted TSS concentration for the three scenarios along the study area. The water quality standard specified in Egyptian law 48/1982 and EPA standards for TSS is $20 \mathrm{mg} / \mathrm{L}$ [10] [14]. The TSS concentration upstream of the Omar-Bek drain was approximately $70 \mathrm{mg} / \mathrm{L}$, which clearly exceeded the limits specified in Egyptian and EPA standards. The TSS concentration at the Damietta branch increased to $72 \mathrm{mg} / \mathrm{L}$ after the branch received discharge from the Omar-Bek drain. Applying the first scenario is expected to decrease the TSS concentration downstream the Omar-Bek drain from 72.0 to $70.0 \mathrm{mg} / \mathrm{L}$. Consequently, applying the first scenario proved ineffective because the Omar-Bek drain slightly increases TSS concentration in the Damietta branch. Applying the second minorly reduces TSS concentration in the Damietta branch, where the TSS concentration downstream the Omar-Bek drain is expected to decrease from 72.0 to $69.50 \mathrm{mg} / \mathrm{L}$ (see Figure 5). The

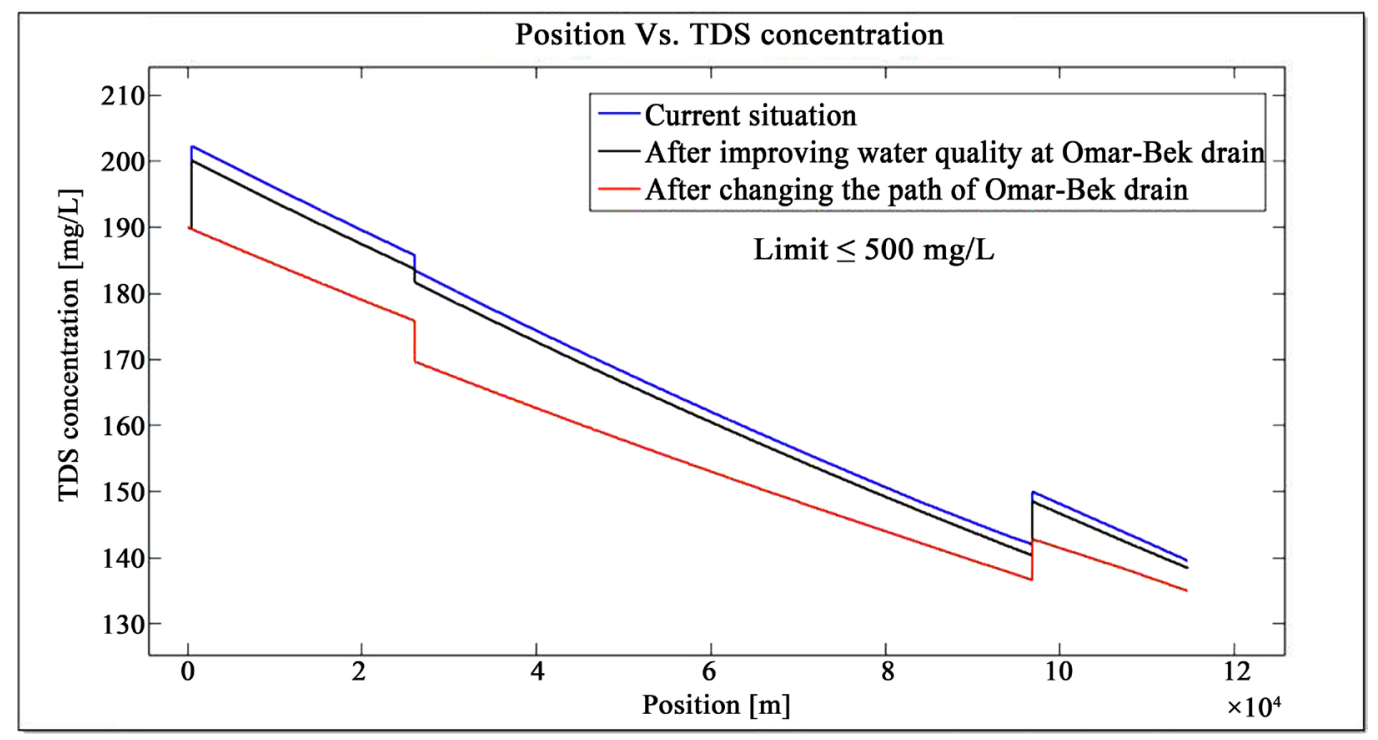

Figure 4. TDS concentration along the Damietta branch for current situation and proposed solutions.

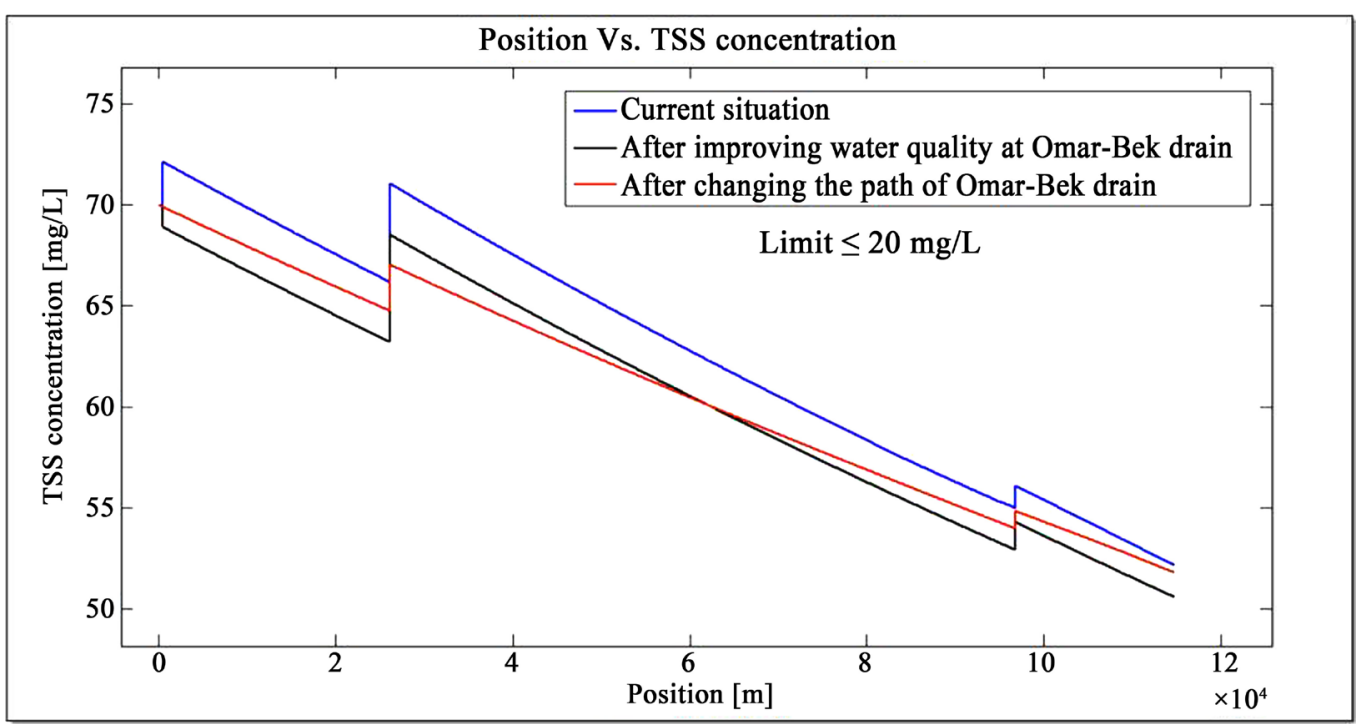

Figure 5. TSS concentration along the Damietta branch for current situation and proposed solutions. 
proposed scenarios will not reduce the TSS concentration at the Damietta branch to the $20 \mathrm{mg} / \mathrm{L}$ water quality standard.

Egyptian law 48/1982 and EPA standards specify a water quality standard of $10 \mathrm{mg} / \mathrm{L}$ for COD [10] [14]. The COD concentration upstream of the Omar-Bek drain measured approximately $8 \mathrm{mg} / \mathrm{L}$, a figure that meets the water quality standards (see Figure 6). After the Damietta branch received discharge from the Omar-Bek drain, the COD concentration increased to $10.2 \mathrm{mg} / \mathrm{L}$, which slightly exceeds the limits specified by Egyptian and EPA standards. Consequently, the COD concentration is not significantly affected by discharge from the Omar-Bek drain. The COD concentration reaches the standard limit at $5.8 \mathrm{~km}$ from the Omar-Bek drain. The highest COD concentration was recorded directly downstream of the Talkha power station, where it reached 14.12, 12.0, and $13.05 \mathrm{mg} / \mathrm{L}$ for the current situation, the first scenario, and the second scenario, respectively. Consequently, the proposed solutions have a minor impact on reducing the COD concentration in the Damietta branch.

According to Egyptian law 48/1982 and EPA standards, the pH value should range between 7.0 and 8.5 [10] [14]. Figure 7 shows the predicted $\mathrm{pH}$ value for the three scenarios along the study area. The $\mathrm{pH}$ value upstream of the Omar-Bek drain was approximately 8.2, a finding consistent with the water quality standards. After discharge was received from the Omar-Bek drain, the $\mathrm{pH}$ value decreased to 8.16, which remains within the limit specified by Egyptian and EPA standards. In the current situation, the $\mathrm{pH}$ value along the study area, range

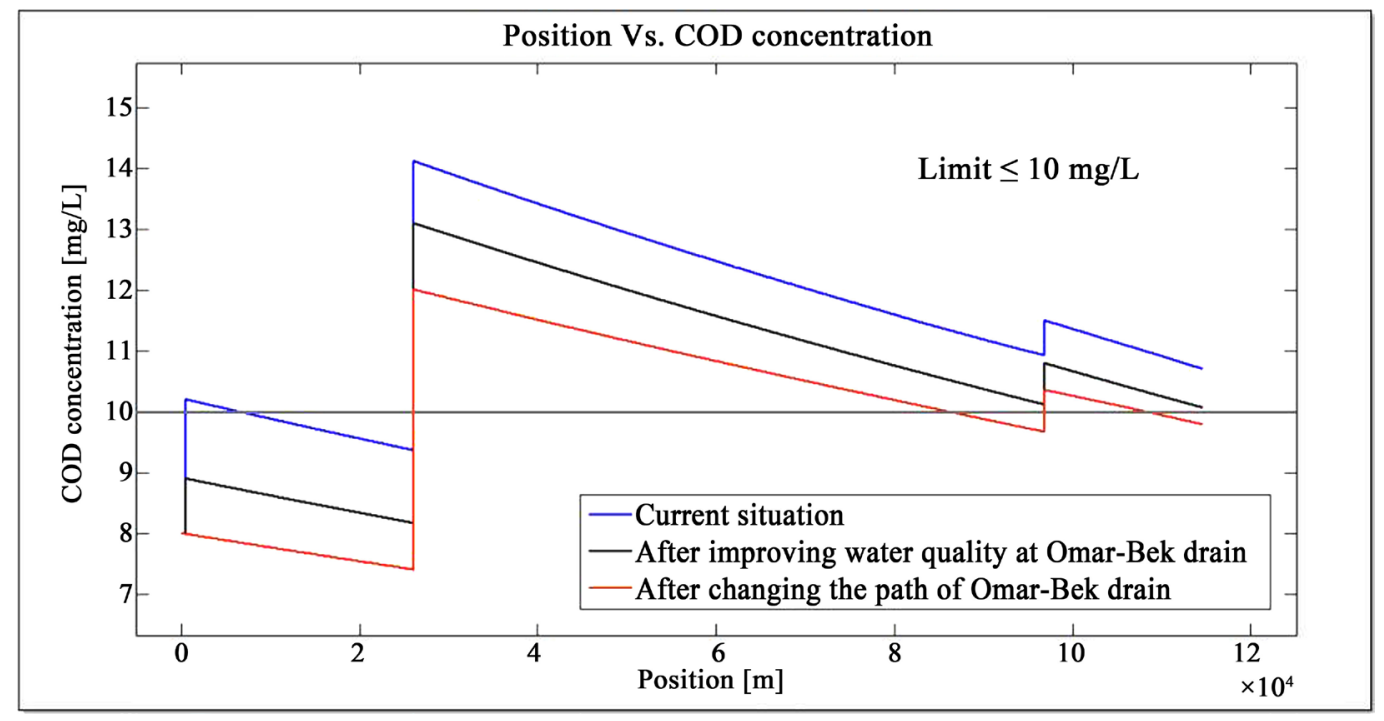

Figure 6. COD concentration along the Damietta branch for current situation and proposed solutions.

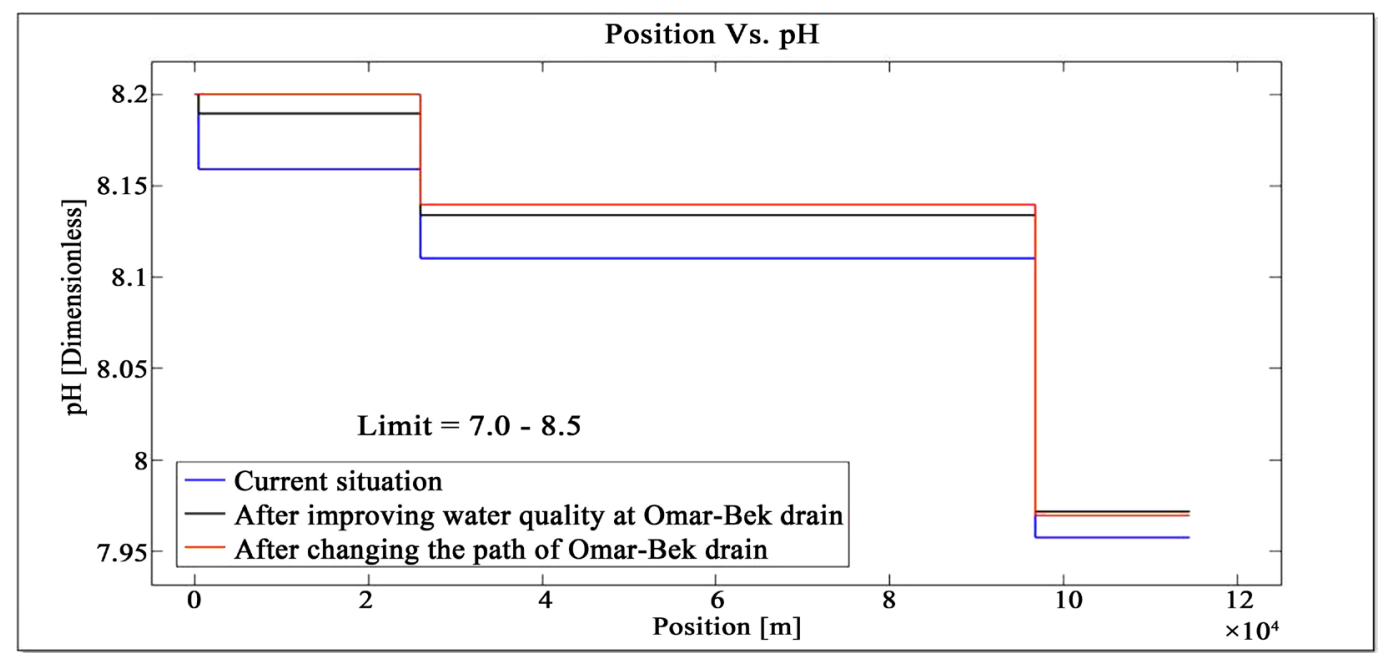

Figure7. pH value along the Damietta branch for current situation and proposed solutions. 
between 7.96 and 8.2, was also found within the limits specified in Egyptian and EPA standards. Consequently, it is not necessary to change the effluent path of the Omar-Bek drain; it has only minor effects of $\mathrm{pH}$ of the Damietta branch. Applying the second scenario has also a minor impact on increasing the $\mathrm{pH}$ level downstream of the Omar-Bek drain, where the pH range between 7.97 and 8.2, as shown in Figure 7.

Figure 8 shows the predicted TOC concentration for the first scenario (changing the effluent path of the Omar-Bek drain) and the second scenario (improving water quality at the Omar-Bek drain by constructing a WWTP and by improving the efficiency of existing WWTPs) along the study area. The recommended TOC concentration in the Damietta branch is $<5.0 \mathrm{mg} / \mathrm{L}$ [10]. The TOC concentration upstream of the Omar-Bek drain measured approximately $0.2 \mathrm{mg} / \mathrm{L}$. The TOC concentrations at the Omar-Bek drain consisted of 1.8 and $1.62 \mathrm{mg} / \mathrm{L}$ for the current situation and for the second scenario, respectively. After the branch received discharge from the Omar-Bek drain, the BOD concentration at the Damietta branch increased to 0.24 and $0.23 \mathrm{mg} / \mathrm{L}$ for the current situation and for the second scenario, respectively. In the case of the first scenario, the TOC concentration upstream of the Omar-Bek drain is approximately equal to the TOC concentration downstream of the drain. Consequently, applying the proposed solutions proved ineffective because the Omar-Bek drain only slightly increases TOC concentration in the Damietta branch.

Figure 9 shows the predicted $\mathrm{Cl}^{-}$concentration for the three scenarios along the study area. The $\mathrm{Cl}^{-}$

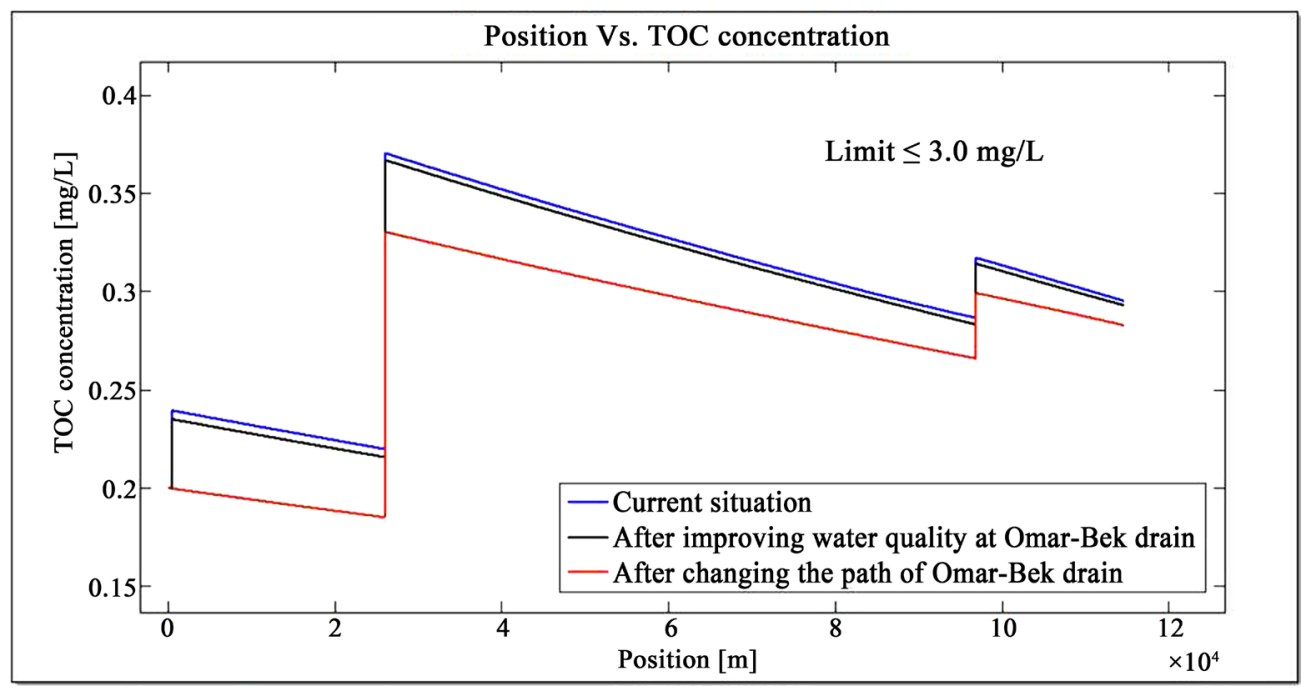

Figure 8. TOC concentration along the Damietta branch for current situation and proposed solutions.

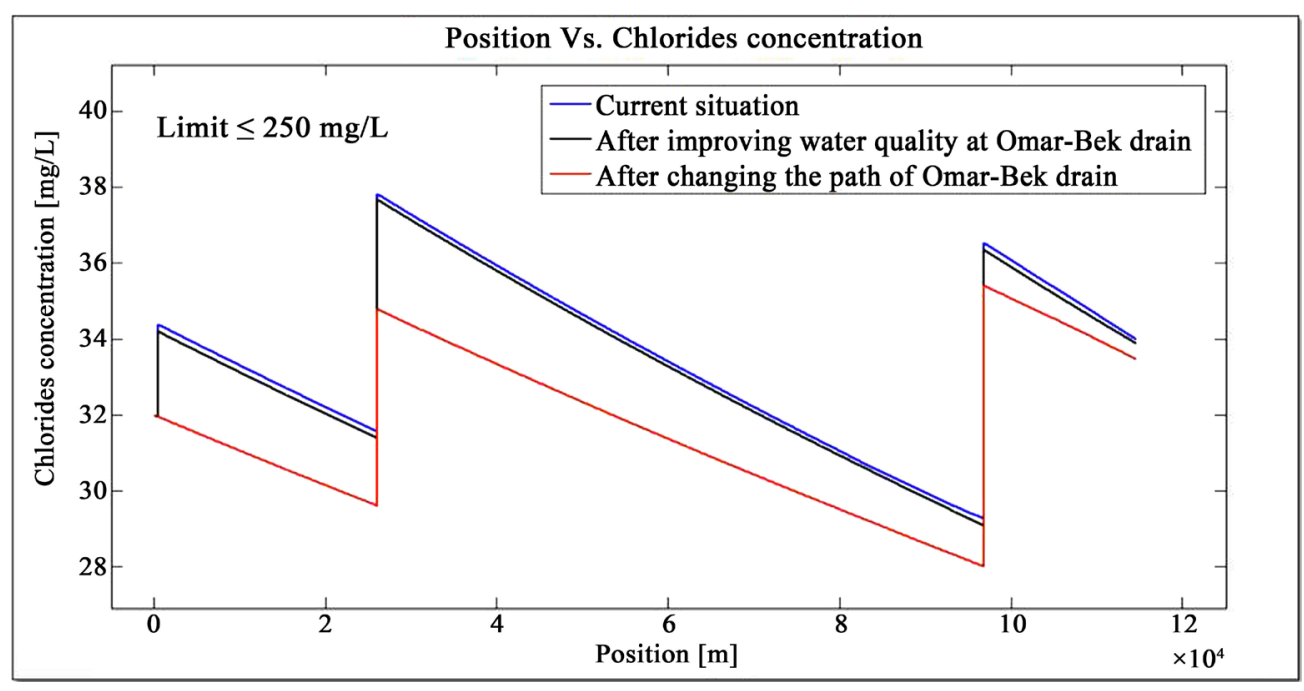

Figure 9. $\mathrm{Cl}^{-}$concentration along the Damietta branch for current situation and proposed solutions. 
concentration upstream of the Omar-Bek drain was approximately $32.0 \mathrm{mg} / \mathrm{L}$. After the Damietta branch received discharge from the Omar-Bek drain, the $\mathrm{Cl}^{-}$concentration is predicted to increase to $34.41 \mathrm{mg} / \mathrm{L}$; this level remains within the limits ( $<250 \mathrm{mg} / \mathrm{L})$ specified by Egyptian law 48/1982 and EPA standards [10] [14]. Consequently, changing the effluent path of the Omar-Bek drain is ineffective because the Omar-Bek drain has only a slight effect on increasing $\mathrm{Cl}^{-}$concentration in the Damietta branch. The second scenario also has a minor impact on reducing the $\mathrm{Cl}^{-}$concentration downstream of the Omar-Bek drain, where the $\mathrm{Cl}^{-}$concentration downstream the Omar-Bek drain is expected to decrease from $34.41 \mathrm{mg} / \mathrm{L}$ to $34.30 \mathrm{mg} / \mathrm{L}$ (see Figure 9).

The RP modeling showed that discharge from the Omar-Bek drain does not significantly affect $\mathrm{pH}$, TSS, TOC, COD, BOD, DO, and $\mathrm{Cl}^{-}$values in the Damietta branch. Ezzat and Reham (2012) also concluded that the concentrations of heavy metals at the Omar-Bek drain and upstream and downstream of the drain did not exceed the permissible limits specified in Egyptian law 48/1982 [5]. Consequently, changing the effluent path of the Omar-Bek drain has a minoreffect on the water quality at the Damietta branch and will result in increasing pollution levels in the Main Western drain, which is used to irrigate different areas in the Kafr El-Sheikh governorate.

\subsection{Cost Estimation}

Cost, also an important parameter, requires consideration during the assessment of any proposed solution for managing water quality. The total cost of changing the effluent path of the Omar-Bek drain reaches about \$25 million, which includes the cost of constructing a drain of $22 \mathrm{~km}$. Because the Omar-Bek drain does not significantly affect Damietta branch water quality and because the cost of changing the path is high, it is recommended that the path of the drain not be changed and that these funds be directed toward more complex problems such as improving the efficiency of the existing WWTPs discharging to the Omar-Bek drain or solving the problem of water quality degradation at the Rosetta branch resulting from discharge from the El-Rahawy drain.

\section{Conclusion}

The RP modeling showed that discharge from the Omar-Bek drain does not significantly affect Damietta branch water quality. The results also showed that improving water quality at the Omar-Bek drain by constructing a WWTP and by improving the efficiency of existing WWTPs is more preferable than changing the path of the drain. Another recommendation for improving water quality at the Omar-Bek drain involves installing sewage networks to prevent the direct discharge to the drain.

\section{Acknowledgements}

This research was supported by the graduate assistant fellowship program (GAFP) and the Department of Civil, Construction, and Environmental Engineering at the University of Alabama at Birmingham. The authors also thank the Egyptian Housing Building Research Center for their help in collecting samples and performing the chemical analyses.

\section{References}

[1] Abdin, A.E. and Gaafar, I. (2009) Rational Water Use in Egypt, Technological Perspectives for Rational Use of Water Resources in the Mediterranean Region. Options Méditerranéennes, 88, 11-27.

[2] Wagdy, A. (2009) Progress in Water Resources Management: Egypt. Proceedings of the 1st Technical Meeting of Muslim Water Researchers Cooperation (MUWAREC), Kuala Lumpur.

[3] Zaidi, M.K. (2007) Wastewater Management in Egypt, Wastewater Reuse-Risk Assessment, Decision-Making and Environmental Security. Springer, Istanbul, 375-382. http://dx.doi.org/10.1007/978-1-4020-6027-4

[4] El-Gammal, H.A.A. (2012) Water Quality Protection in Rural Areas of Egypt. International Water Technology Journal, 1, 230-238.

[5] Ezzat, S.M. and Reham, M.E. (2012) Omar Bek Drain Water Quality and Its Impact on Damietta Branch, River NileEgypt. American-Eurasian Journal of Agricultural \& Environmental Sciences, 12, 472-483.

[6] Drews, C. and Han, W.Q. (2010) Dynamics of Wind Setdown at Suez and the Eastern Nile Delta. PLoS ONE Community Blog, 5. http://www.plosone.org/article/info:doi/10.1371/journal.pone.0012481 http://dx.doi.org/10.1371/journal.pone.0012481 
[7] Mostafa, M. (2014) Modeling of Pollutant Transport in the Nile Delta Egypt. Ph.D. Dissertation, University of Alabama at Birmingham, Birmingham.

[8] Moussa, A.M.A. and Medhat, S.A. (2007) Nile River Sediment Transport Simulation (Case Study: Damietta Branch). Eleventh International Water Technology Conference, IWTC11, Sharm El-Sheikh.

[9] Abdo, M.H. (2010) Environmental and Water Quality Evaluation of Damietta Branch, River Nile, Egypt. African J. Biol. Sci., 6, 143-158.

[10] National Water Research Center (NWRC) (1995) River Nile Protection and Development Project Phase II, Environmental Pollution and Legislative Regulations (Law 48. 1982 \& Decree 8, 1993). Ministry of Public Works and Water Resources, Cairo.

[11] Bitton, G. (2011) Wastewater Microbiology. John Wiley \& Sons, Inc., Hoboken.

[12] Chapra, S.C. (1997) Surface Water Quality Modeling. McGraw-Hill Publisher, New York.

[13] Andrew, D.E., Lenore, S.C., Eugene, W.R. and Arnold, E.G. (2005) Standard Methods for the Examination of Water and Wastewater. 21st Edition, American Public Health Association, Washington DC.

[14] Environmental Protection Agency (EPA) (2007) Drinking Water Standards and Health Advisories Table. Office of Research and Development, San Francisco. http://www.epa.gov/region9/water/drinking/files/dwsha 0607.pdf 